\title{
Pulmonary and Systemic Expression of Monocyte Chemotactic Proteins in Preterm Sheep Fetuses Exposed to Lipopolysaccharide-Induced Chorioamnionitis
}

\author{
TUSHAR A. SHAH, NOAH H. HILLMAN, ILIAS NITSOS, GRAEME R. POLGLASE, J. JANE PILLOW, JOHN P. NEWNHAM,
} ALAN H. JOBE, AND SUHAS G. KALLAPUR

\begin{abstract}
Divisions of Neonatology and Pulmonary Biology [T.A.S., N.H.H., A.H.J., S.G.K.], Cincinnati Children's Hospital Medical Center, University of Cincinnati, Cincinnati, Ohio 45229; Divisions of Neonatology [J.J.P., A.H.J., S.G.K.] and Obstetrics/Gynecology [I.N., J.P.N.], School of Women's and Infants' Health, University of Western Australia, Crawley 6009, Australia
\end{abstract}

\begin{abstract}
Monocyte chemoattractant proteins (MCP-1 and MCP-2) mediate monocyte and T-lymphocyte chemotaxis, and IL-1 contributes to the pathogenesis of chorioamnionitis-induced lung inflammation and fetal inflammatory responses. We tested the hypothesis that IL-1 mediates the systemic and pulmonary induction of MCP-1 and MCP-2 in response to lipopolysaccharide (LPS)-induced chorioamnionitis. MCP-1 mRNA, MCP-2 mRNA, and MCP-1 protein expression were measured in two models: 1) intra-amniotic LPS and 2) intra-amniotic recombinant sheep IL-1 $\alpha$ given at varying intervals before preterm delivery at $124 \mathrm{~d} \mathrm{GA}$. Intra-amniotic LPS or IL- $1 \alpha$ induced MCP- 1 mRNA and protein and MCP-2 mRNA in fetal lung many fold at 1-2 d. LPS induced intense MCP-1 expression in subepithelial mesenchymal cells and interstitial inflammatory cells in the lung. Inhibition of IL-1 signaling with recombinant human IL-1 receptor antagonist (rhIL-1ra) did not attenuate LPS induced increase in MCP-1 or MCP-2 expression. MCP-1 and MCP-2 were not induced in liver or chorioamnion, but MCP-1 increased in cord plasma. LPS or IL-1 can induce robust expression of MCP-1 or MCP-2 in the fetal lung. LPS induction of MCP-1 is not IL-1 dependent in fetal sheep. MCP-1 and MCP-2 may be significant contributors to fetal inflammation. (Pediatr Res 68: 210-215, 2010)
\end{abstract}

$\mathrm{C}$ horioamnionitis is associated with the majority of preterm births before 28 wk gestation in the United States $(1,2)$. Although preterm infants less than $30 \mathrm{wk}$ gestation are only $\sim 1.5 \%$ of the $\sim 4$ million births in the United States, they account for $70 \%$ of the neonatal mortality. Although multiple cytokines are thought to contribute to preterm labor and delivery (3), MCP-1 is the most predictive cytokine for preterm birth in women with a short cervix (4). MCP-1 is also increased in the amniotic fluid of women who deliver preterm after mid-trimester amniocentesis (5). This cytokine is increased in cervical secretions, amniotic fluid, and placental tissues from preterm deliveries associated with chorioamnionitis (6-8). MCP-1 is also increased in the bronchoalveolar lavage fluid (BALF) and plasma of infants with oxidant injury, who subsequently develop bronchopulmonary dysplasia (BPD) $(9,10)$. BPD develops in $\sim 48 \%$ of infants born at $<28$

Received February 3, 2010; accepted April 28, 2010.

Correspondence: Suhas G. Kallapur, M.D., Division of Pulmonary Biology, Cincinnati Children's Hospital Medical Center, University of Cincinnati, 3333 Burnet Avenue, Cincinnati, OH 45229-3039; e-mail: suhas.kallapur@cchmc.org

Supported by Grants HL-65397 and HD-57869 from the National Institutes of Health. wk gestation (11). Chorioamnionitis is associated with a systemic inflammatory response and adverse neurologic and gastrointestinal outcomes in premature infants $(12,13)$.

The subfamily of CC chemokines includes MCP-1, MCP-2, MCP-3, MCP-4, MCP-5, and eotaxin. Both MCP-1 and MCP-2 bind and signal through a 7-transmembrane spanning G protein-coupled receptor, CCR2 (14). MCP-1 is one of the key chemokines that regulate migration and infiltration of monocytes/macrophages (15). Both MCP-1 and its receptor CCR2 are important mediators in inflammatory diseases such as multiple sclerosis and atherosclerosis $(16,17)$.

Intra-amniotic injection of lipopolysaccharide (LPS) in sheep recruits neutrophils and monocytes to the fetal lung and results in lung injury responses similar to BPD (18). This LPS-mediated recruitment is CD18 and IL-1 dependent $(18,19)$. Intra-amniotic IL-1 also causes recruitment of monocytes and neutrophils to the fetal lung $(20,21)$. IL-1 transcriptionally controls induction of MCP-1 and MCP-2 in in vitro systems (22).

Given the importance of MCP in monocyte chemotaxis in adult inflammatory diseases and its prominent association with prematurity, we explored induction of MCP-1 and MCP-2 by LPS and IL-1 in preterm fetal sheep. To test the hypothesis that MCP-1 and MCP-2 induction by intraamniotic LPS is IL-1 dependent, we used two models of chorioamnionitis: intra-amniotic injection of LPS or IL-1. IL-1 signaling also was inhibited with a recombinant human IL-1 receptor antagonist (rhIL-1ra) (19). We measured the expression of MCP-1 mRNA and protein, and MCP-2 mRNA in the lung, liver, chorioamnion, and plasma and localized MCP-1 in the lung.

\section{MATERIALS AND METHODS}

\footnotetext{
Animals. Fetal sheep were sampled in Western Australia with approva from the animal care and use committees of Cincinnati Children's Hospital
} 
(Cincinnati, OH) and the University of Western Australia (Perth, WA, Australia). In separate protocols, date-mated Merino ewes with singleton fetuses were randomly assigned to the following groups ( $n=5-9 /$ group): 1 ) $10 \mathrm{mg}$ of LPS (E. coli 055:B5; Sigma Chemical Co., St. Louis, MO), given by intra-amniotic injections at $2 \mathrm{~h}, 5 \mathrm{~h}, 2 \mathrm{~d}$, or $7 \mathrm{~d}$ before delivery. 2) $100 \mu \mathrm{g}$ of recombinant sheep IL- $1 \alpha$ (Protein Express, Cincinnati, OH), given by intra-amniotic injection 1, 2, 4, or $7 \mathrm{~d}$ before delivery, 3) $100 \mathrm{mg}$ rhIL-1ra (Anakinra [Kineret]; Amgen, Inc., Thousand Oaks, CA) or saline given by intra-amniotic injection $3 \mathrm{~h}$ before intra-amniotic LPS $(10 \mathrm{mg}$ ) or saline injection (19). Animals delivered $2 \mathrm{~d}$ after LPS exposure received only one dose of rhIL-1ra, and animals delivered 6 or $7 \mathrm{~d}$ after LPS exposure received two additional intra-amniotic 100-mg doses of rhIL-1 ra or saline treatment at 2 and $4 \mathrm{~d}$ (19). All animals were surgically delivered at $124 \mathrm{~d} \mathrm{GA} \mathrm{(83 \%} \mathrm{term}$ gestation), at which the fetal sheep is in an early alveolar stage of lung development, roughly corresponding structurally to a human equivalent of 32-34 wk (23). Control animals were injected with an equivalent $2 \mathrm{~mL}$ volume of saline. The lung maturational and inflammatory responses to LPS, IL-1 $\alpha$, and IL-1ra for these animals were previously reported (19). Intraamniotic injections were given with ultrasound guidance with verification of needle placement by electrolyte analysis of amniotic fluid (19). The biologic efficacy of the dose and route of administration of rhIL-1ra in the sheep was verified by demonstrating that the same lot of rhIL-1ra completely inhibited intraamniotic and i.v. IL- $1 \alpha$ induced lung and systemic inflammation (reported in the online section of Ref. 19).

Tissue processing. Plasma from heparinized cord blood was collected. BALF was recovered from the left lung using three normal saline lavages to total lung capacity (19). The right upper lobe of lung was inflation fixed with $10 \%$ buffered formalin at $30 \mathrm{~cm} \mathrm{H}_{2} \mathrm{O}$ pressure. Pieces of the liver, chorioamnion, and the right lower lobe of the lung were snap-frozen for RNA analysis.

Quantitation of $\boldsymbol{m R N A}$. Total RNA was isolated using a modified Chomczynski method from lung, liver, and chorioamnion (24). The sheep MCP-1 cDNA clone [pGEMT-MCP-1] was cut with SpeI, and an antisense riboprobe with a 268 nucleotide-protected fragment was synthesized using T7 RNA polymerase. The sheep MCP-2 cDNA clone [pGEMT-MCP-2] was cut with Bsa1, and an antisense riboprobe with a 190 nucleotide-protected fragment was synthesized using T7 RNA polymerase. Ten micrograms of RNA were used for RNase protection assays with the antisense MCP-1 or MCP-2 riboprobes. Solution hybridization was performed as reported (24). The probe for $\mathrm{L} 32$, a ribosomal protein mRNA, was included in each assay as an internal standard. Protected fragments were resolved on $6 \%$ polyacrylamide $8 \mathrm{M}$ urea gels, visualized by autoradiography and quantified on a Phosphor Imager using Image Quant version 1.2 software (Molecular Dynamics, Sunnyvale, CA).

mRNA localization in lung. In situ hybridization was used to localize MCP-1 mRNA expression in paraffin-embedded sections with a digoxigeninlabeled antisense riboprobe ([pGEMT-MCP-1] cut with NotI). The plasmid MCP-1 was digested with NotI for the antisense probe (T7 polymerase; Promega) and with $\mathrm{NcoI}$ for the sense probe (SP6 polymerase; Promega). The riboprobe was generated in an in vitro transcription reaction using digoxigenin-UTP (Roche). For hybridization, the sense and antisense probes were diluted in hybridization buffer to a final concentration of $1 \mu \mathrm{g} / \mathrm{mL}(100$ $\mu \mathrm{L} /$ section) and incubated at $57^{\circ} \mathrm{C}$. After hybridization, sections were washed with a buffer containing $50 \%$ formamide for $30 \mathrm{~min}$ at $65^{\circ} \mathrm{C}$. Sections were then treated with RNase A/T1 to reduce nonspecific binding followed by washes. An anti-digoxigenin antibody conjugated with alkaline phosphatase was applied $\left(1 / 2000\right.$; Roche) overnight at $4^{\circ} \mathrm{C}$ followed by reacting with an alkaline phosphatase substrate containing nitro blue tetrazolium chloride (Roche). Controls for specificity of riboprobe binding included lung tissues obtained from lambs exposed to intra-amniotic saline and homologous (sense) probes.

Anti MCP-1 antibodies. Recombinant sheep MCP-1 protein was synthesized using a cloned full-length sheep MCP-1 subcloned into an expression vector (Protein Express, Cincinnati). Anti MCP-1 antibodies were generated in house in guinea pigs and rabbits by injecting the recombinant sheep MCP-1 protein using standard techniques for generation of polyclonal antibodies (25).

Immunohistochemistry. Immunostaining was done on paraffin-embedded sections using antigen retrieval ( $0.1 \mathrm{M}$ citrate with microwave boiling) as previously reported (26). The following primary antibodies were used: a) goat polyclonal antibody against vimentin (Santacruz Biotechnology, CA; catalogue \#sc7557, dilution 1:50), b) guinea pig anti-MCP1 antiserum (1:250) (Seven Hill Bioreagents, Cincinnati, $\mathrm{OH}$ ), and c) anti-smooth muscle actin (Sigma Chemical Co., St. Louis, MO; catalogue\# 5228, dilution 1:5000). After the slides were washed with PBS to remove unbound antibody, they were incubated with the secondary biotinylated antibody against rabbit $\operatorname{IgG}$ (Vector Laboratories, Burlingame, CA; dilution 1:200) or the appropriate fluorescently labeled secondary antibodies for colocalization experiments (dilution 1:200). For the experiments using biotinylated antibodies, avidin (Vector Laboratories) was added and staining for positive cells was developed with diaminobenzidine and cobalt with a nuclear fast red counterstain. Specificity of staining was demonstrated by the ability of excess peptide to compete with the antibody signal and by using lung sections from control animals.

Protein quantitation. MCP-1 protein was quantified in undiluted alveolar wash and cord plasma. We developed a sandwich ELISA assay for measuring MCP-1 in fluids using a) IgG fraction of rabbit anti-sheep MCP-1 serum as a coating antibody and b) guinea pig anti-sheep MCP-1 serum for the detection antibody (19). Standard curves were constructed using serial dilutions of recombinant sheep MCP-1. The lowest detection limit of this assay was 0.1 $\mathrm{ng} / \mathrm{mL}$ with a dynamic range of $0.1-80 \mathrm{ng} / \mathrm{mL}$ and a correlation coefficient of 0.99 for all assays.

Statistics. All values were expressed as means \pm SEM. ANOVA was used for comparison of differences between groups with Dunn's multiple comparison test used for post hoc analysis. The unpaired $t$ test with Welch correction was used for comparison between two groups. Significance was accepted at $p<0.05$ (two-tailed).

\section{RESULTS}

Expression of MCP-1 in fetal lung. MCP-1 mRNA expression increased 4 -fold at $2 \mathrm{~h}, 7$-fold at $5 \mathrm{~h}$, by over 50 -fold at 1 and $2 \mathrm{~d}$, and returned to control levels at $7 \mathrm{~d}$ after intraamniotic LPS (Fig. 1A). Intra-amniotic IL-1 induced MCP-1 mRNA 56-fold in the lung at $1 \mathrm{~d}$ with interanimal variability and returned to baseline levels at 4-7 d after exposure (Fig. $1 D)$. Consistent with the mRNA expression MCP-1 protein increased in BALF after intra-amniotic LPS (Fig. 1B) and after intra-amniotic IL-1 (Fig. 1E).

MCP-1 in nonpulmonary tissues. The mRNA for MCP-1 was not detected in chorioamnion or fetal liver after intraamniotic injections of LPS or IL- $1 \alpha$ (data not shown). In contrast, MCP-1 protein was not present in cord plasma from control lambs but increased in cord plasma after intraamniotic LPS (Fig. 1C) or IL-1 (Fig. 1F).

Localization of MCP-1 MRNA and protein in fetal lung. Intra-amniotic LPS induced intense MCP-1 mRNA expression in the mesenchyme around large airways within $5 \mathrm{~h}$, with more diffuse expression by 1 and $2 \mathrm{~d}$ throughout the mesenchyme and in inflammatory cells (Fig. 2). Consistent with the mRNA expression, MCP- 1 protein was detected in the mesenchymal cells surrounding the airways at $5 \mathrm{~h}$ (Fig. $3 B$ ) and $1 \mathrm{~d}$ (Fig. 3C), with protein localized primarily to inflammatory cells by $2 \mathrm{~d}$ (Fig. $3 D$ ). To further localize the mesenchymal cells expressing MCP-1 at $5 \mathrm{~h}$ after LPS exposure, we performed colocalization immunostaining experiments using the combination antibodies against: MCP1 + alpha-smooth muscle actin or MCP1 + vimentin. The cells expressing MCP-1 did not express alpha-smooth muscle actin (data not shown) indicating that the cells were not of smooth muscle or myofibroblast origin. However, a large number of the MCP-1 expressing cells also expressed vimentin (Fig. $3 E-G$ ). The results are consistent with the predominant expression of MCP-1 in the fibroblasts early after LPS exposure.

LPS-induced MCP-1 expression is not IL-1 dependent. In separate groups of animals given intra-amniotic IL-1ra followed by LPS, the LPS exposure greatly increased the mRNA for MCP-1 in lung tissue, the amount of MCP-1 protein in BALF, and the MCP-1 protein in cord plasma (Fig. 4). Prior exposure to intra-amniotic rhIL-1ra did not change the LPS induced increases in MCP-1 in the lung or the cord plasma.

MCP-2 expression in fetal lung. In patterns similar to MCP-1, MCP-2 expression greatly increased after intra- 

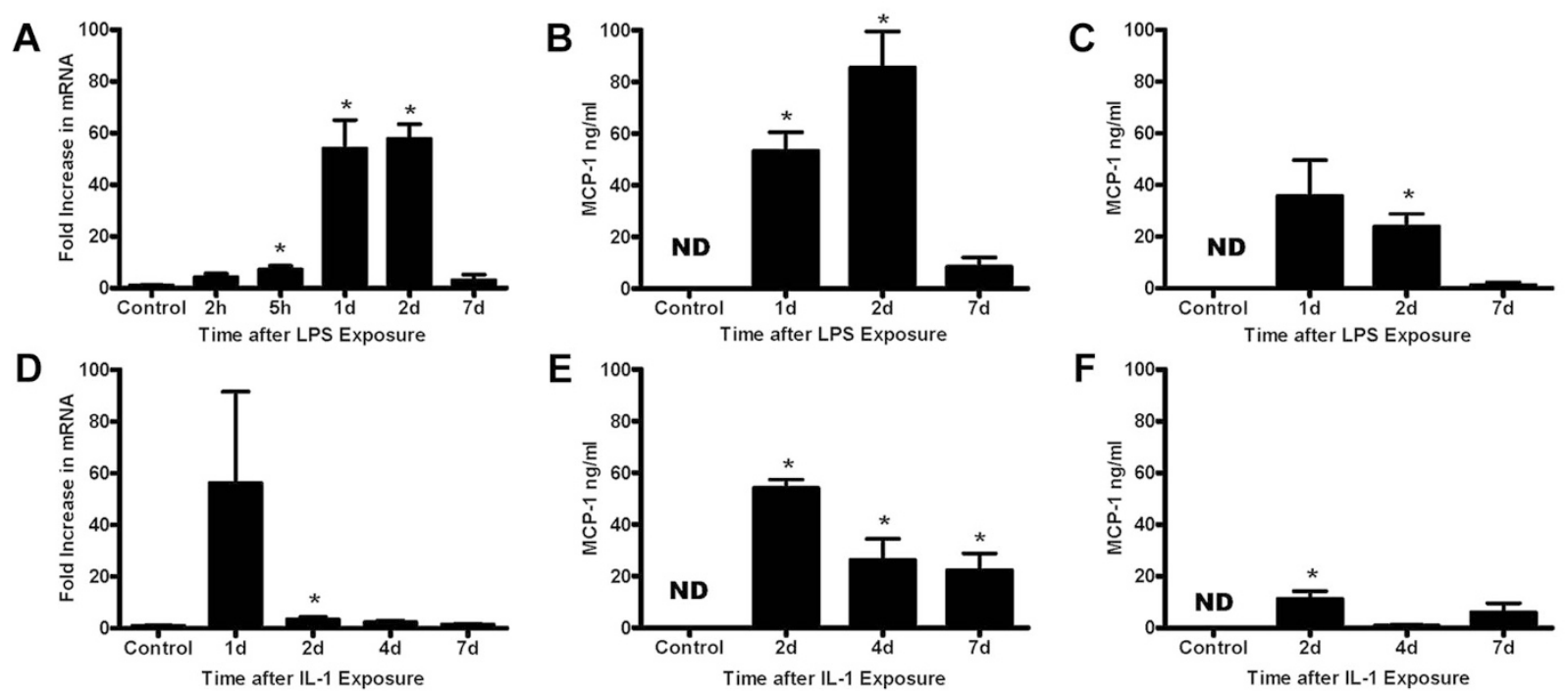

Figure 1. MCP-1 expression induced by intra-amniotic LPS or IL-1 $\alpha$. Quantification of MCP-1 mRNA (normalized to L32) from fetal lung using RNAse protection assays after $(A)$ intra-amniotic LPS exposure or $(D)$ intra-amniotic IL-1 exposure. Mean mRNA signals in control animals were given the value of 1 and levels at each time point were expressed relative to controls. MCP-1 protein (ng/mL) was quantified in BALF using ELISA after $(B)$ intra-amniotic LPS or $(E)$ intra-amniotic IL-1 exposures. MCP-1 protein $(\mathrm{ng} / \mathrm{mL})$ was quantified in cord plasma after $(C)$ intra-amniotic LPS or $(F)$ intra-amniotic IL-1. * $p<0.05$ vs control; ND, not detected.

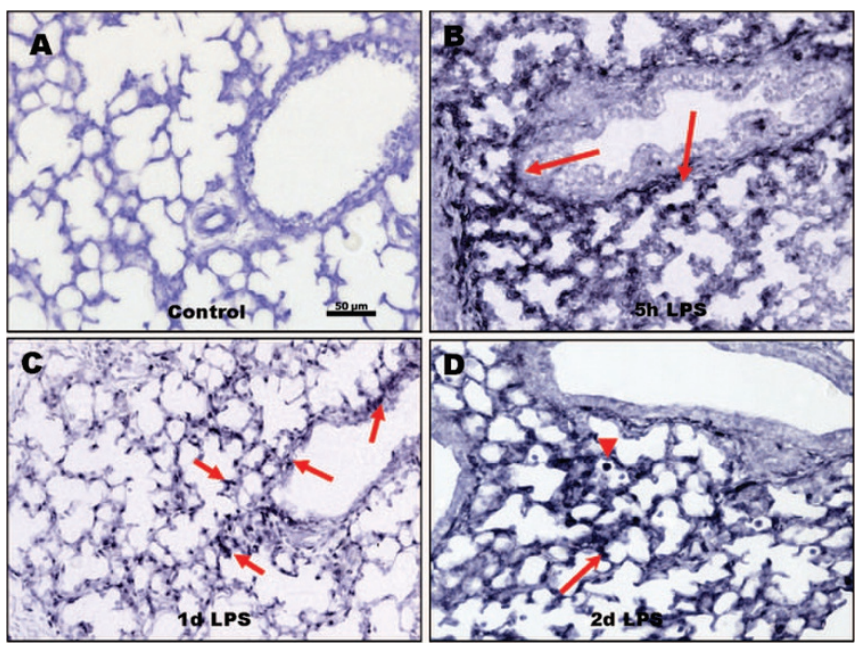

Figure 2. Localization of MCP-1 mRNA in fetal lung. In situ hybridization was performed using a digoxigenin labeled anti-sense sheep MCP-1 riboprobe. (A) Saline controls had no MCP-1 mRNA expression. (B) MCP-1 mRNA expression (dark blue staining) was detected in the lung mesenchyme around the larger airways (arrow) as early as $5 \mathrm{~h}$ after intra-amniotic LPS. (C) MCP-1 mRNA expression was in the lung mesenchyme and inflammatory cells (arrowhead) $1 \mathrm{~d}$ after intra-amniotic LPS. (D) By $2 \mathrm{~d}$, the mRNA signal was less apparent around the larger airways with intense MCP-1 mRNA expression in the lung mesenchyme and inflammatory cells. Scale bar is $50 \mu \mathrm{m}$.

amniotic LPS or IL-1 (Fig. $5 A$ and $B$ ). In a separate experiment, the IL-1ra inhibition of IL-1 signaling did not change the increase in MCP-2 mRNA at $2 \mathrm{~d}$ (Fig. 5C).

\section{DISCUSSION}

We initially identified MCP-1 as a gene that was highly induced in fetal lung after intra-amniotic LPS in a subtraction hybridization screen (27). We have now explored the expression of MCP-1 and MCP-2 in preterm fetal sheep models of chorioamnionitis. MCP-1 and MCP-2 are robustly induced in
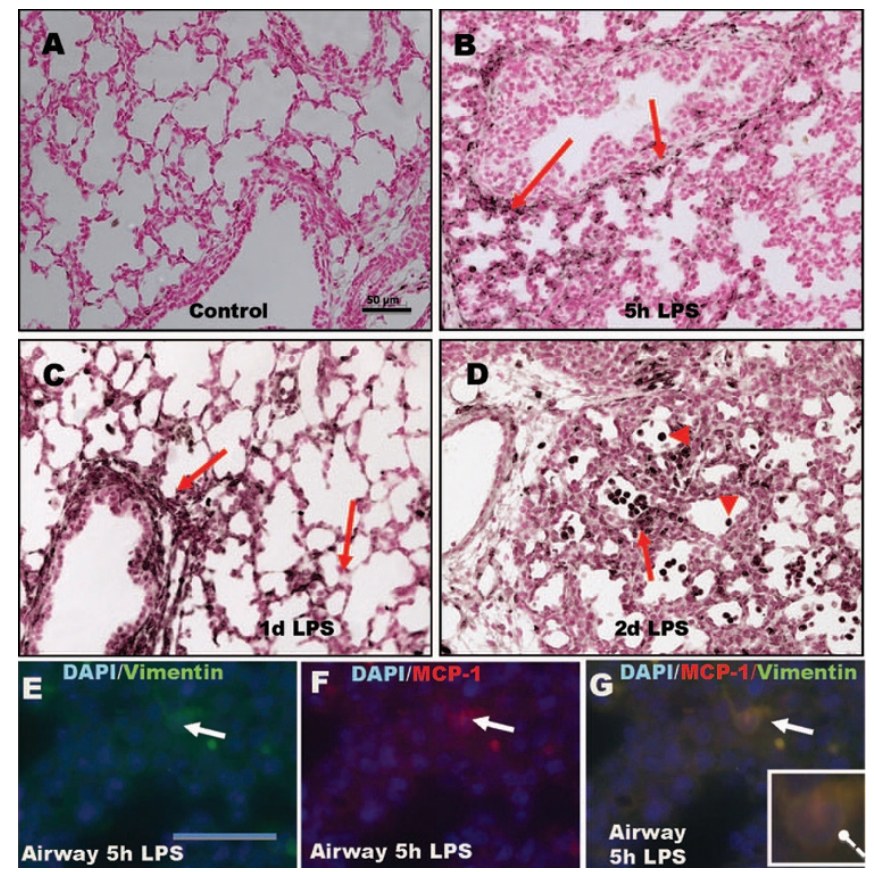

Figure 3. Localization of MCP-1 protein in fetal lung. Immunohistochemistry was performed using guinea pig anti-sheep MCP-1. (A) There was no MCP-1 protein detected in control lungs. $(B) \mathrm{MCP}-1$ protein (dark brown stain) was apparent in the lung mesenchyme, around the larger airways, within $5 \mathrm{~h}$ of intra-amniotic LPS. (C) MCP-1 protein also was expressed in the lung mesenchyme (arrow) and inflammatory cells (arrowhead) $1 \mathrm{~d}$ after intra-amniotic LPS. (D) MCP-1 protein was primarily in inflammatory cells at $2 \mathrm{~d}$. Colocalization was done using fluorescently labeled antibodies using lung sections from lambs $5 \mathrm{~h}$ after exposure to LPS. (E) DAPI staining nuclei blue with vimentin (green). $(F)$ DAPI with MCP-1 (red). $(G)$ Merged picture with DAPI, vimentin, and MCP-1 antibodies. The white arrow in $E, F$, or $G$ points to a mesenchymal cell, whereas the small bright fluorescent signal adjacent to the arrow is a red blood cell. The inset in panel $G$ shows a higher power of mesenchymal cell with a nucleus stained blue (shown by a round arrow) surrounded by an orange staining indicating localization of MCP-1 and vimentin to the cytoplasm. Scale bar is $50 \mu \mathrm{m}$. 

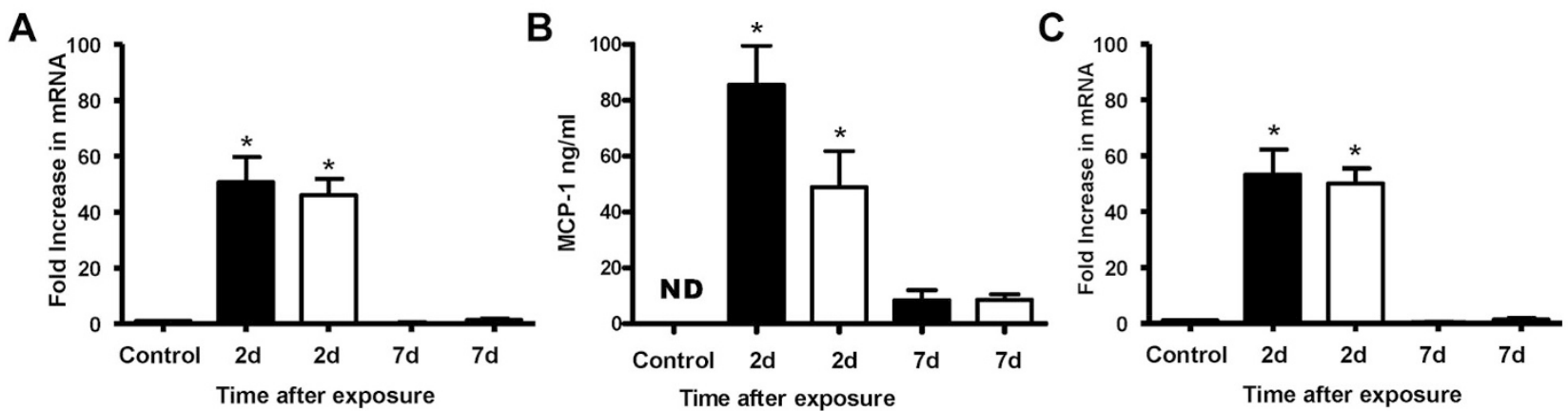

Figure 4. LPS-induced MCP-1 expression is not IL-1 dependent. (A) Quantification of MCP-1 mRNA (normalized to L32) from fetal lung using RNAse protection assays after intra-amniotic LPS and intra-amniotic LPS + rhIL-1ra exposures. Mean mRNA signal in control animals was given the value of 1, and levels at each time point were expressed relative to controls. (B) Quantification of MCP-1 protein $(\mathrm{ng} / \mathrm{mL})$ from BALF, and $(C)$ in cord plasma after intra-amniotic LPS and intra-amniotic LPS + rhIL-1 ra exposure. The rhIL-1ra did not change MCP-1 expression in response to LPS. The dark bars represent animals exposed to intraamniotic LPS only, whereas the open bars represent animals exposed to intraamniotic LPS + rhIL-1ra $\left({ }^{*} p<0.05 v s\right.$ control).
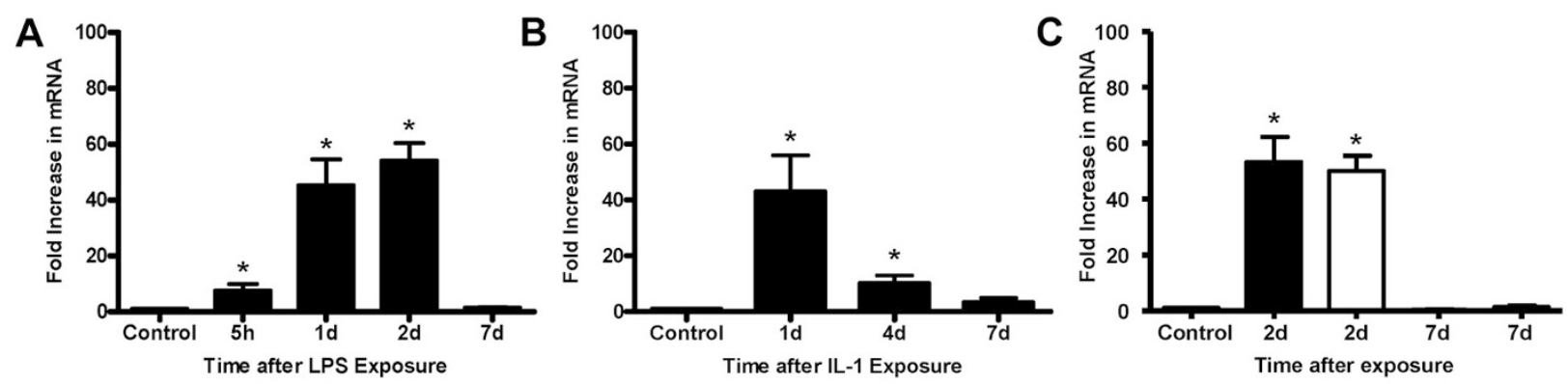

Figure 5. LPS-induced MCP-2 expression is not IL-1 dependent. Time-course and quantification of MCP-2 mRNA (normalized to L32) from fetal lung using RNAse protection assays $(A)$ after intra-amniotic LPS, $(B)$ after intraamniotic IL-1 $\alpha$ exposure, and $(C)$ after intra-amniotic LPS + rhIL-1ra exposures. Mean mRNA signal in control animals was given the value of 1 , and levels at each time point were expressed relative to controls. The rhIL-1ra did not change MCP-2 expression in response to LPS. The dark bars represent animals exposed to intraamniotic LPS only, whereas the open bars are animals exposed to intraamniotic LPS + rhIL-1ra $(* p<0.05$ vs control).

the fetal lung after intra-amniotic LPS or IL-1. Soon after fetal exposure to LPS, expression of MCP-1 was detected in resident lung cells, primarily the mesenchymal fibroblasts. The LPS-induced MCP-1 and MCP-2 expression was not dependent on IL-1 because blocking the IL-1 receptor did not change MCP-1 or MCP-2 expression. There was no significant MCP-1 or MCP-2 expression in the fetal liver or chorioamnion, although MCP-1 was increased in cord plasma. The origin of the plasma MCP-1 is not known, but could be from lung or circulating inflammatory cells. MCP-1 is implicated in the pathogenesis of preterm labor and BPD (6-10), diseases commonly associated with infants born prematurely. However, in these diseases, many other cytokines are also upregulated. Understanding the hierarchical regulation of the cytokine networks will enable study of the pathogenesis of inflammation in these diseases. The results of this study demonstrate that either signaling via a TLR4 receptor or IL-1 receptor in the setting of chorioamnionitis can induce MCP expression in the lung.

MCP-1 and MCP-2 are mediators of monocyte recruitment in the lung and other organs. Experiments using CCR2 $2^{-1-} \&$ MCP-1 $1^{-1-}$ mice demonstrate that MCP-1 is required for monocyte recruitment $(15,28,29)$. A neutralizing antibody to MCP-1 inhibited monocyte and neutrophil recruitment to the injured lung (30). In fetal sheep, intra-amniotic LPS induced pulmonary recruitment of neutrophils and monocytes is CD18 dependent (18). IL-1 is a major down-stream contributor to LPS induced lung inflammation in fetal sheep, because inhibition of rhIL-1 signaling by IL-1ra decreased LPS-mediated proinflammatory cytokine expression and the recruitment of monocytes and neutrophils to the fetal lungs by $\sim 70 \%$ (19).

In the present experiments, there was a trend toward decreased LPS induced MCP-1 expression in the BALF of the lambs after blockade of IL-1 signaling (Fig. $4 B, p=0.08$ for LPS versus LPS + rhIL-1ra). Although, the result could be due to a type II error, the more likely explanation is that there were fewer cells in the BALF for the LPS + rhIL-1ra group compared with the LPS group as reported previously (19). Indeed, when BALF MCP-1 expression was normalized to the number of inflammatory cells, the corresponding values for MCP-1 levels were $46 \pm 6 \mathrm{ng} / 10^{6}$ cells ( $2 \mathrm{~d}$ LPS group) versus $198 \pm 119 \mathrm{ng} / 10^{6}$ cells $(2 \mathrm{~d}$ LPS + rhIL-1 ra $)(p=0.3)$. These results are consistent with the interpretation that while IL-1 signaling partially mediates LPS induced pulmonary inflammatory cell recruitment, it does not mediate pulmonary MCP-1 expression. It is interesting that at $2 \mathrm{~d}$ after LPS exposure, there was a correlation between BALF MCP-1 level and neutrophil counts $\left(R^{2}=0.76\right)$ and a more modest correlation with monocyte counts $\left(R^{2}=0.17\right)$. However, the precise role of MCP-1 in fetal monocyte or neutrophil recruit- 
ment is not known since an inhibitor of MCP signaling for testing in sheep is not yet available. Similarly, we could not characterize the expression and modulation of the MCP-2 protein expression or the MCP receptor CCR2 in these experiments because of lack of appropriate reagents. Taken together, our data suggest that MCP-1 and IL-1 may both contribute to inflammatory cell recruitment in response to a TLR4 agonist.

LPS signals via TLR4 whereas IL-1 signals via IL-1R, but both agonists share similar intracellular signaling pathways (31). While LPS and IL-1 induce many genes in common, they also induce distinct sets of genes in the fetal lung. For example, the interferon inducible genes IP-10 and MIG are induced by LPS but not IL-1 (27), whereas IL-1 $\beta$, IL-6, IL-8, and SAA3 are induced by both LPS and IL-1 (19). SAA3 and MCP-1 induction by LPS is not IL-1 dependent in the fetal sheep while recruitment of inflammatory cells is partially IL-1 dependent $(19,32)$. These experiments inform us of the cytokine regulatory networks induced by a TLR agonist in vivo.

Fetal inflammatory response syndrome is a poorly characterized entity that is associated with umbilical cord inflammation and increased plasma cytokine levels in the absence of bacteremia $(33,34)$. A systemic inflammatory response induced by chorioamnionitis is postulated to be the proximate cause of fetal organ injuries such as periventricular leukomalacia (35), necrotizing enterocolitis (12), or BPD $(12,35)$. Exposure of fetal sheep to LPS-mediated chorioamnionitis increases MCP-1 in cord blood, which may contribute to the fetal inflammatory response $(18,19)$. A caveat of the LPSchorioamnionitis model is that the proinflammatory agonist used in these experiments is the LPS derived from Gramnegative organisms, while the most common bacteria isolated from placenta of preterm infants with chorioamnionitis are the Ureaplasma species (36). Despite these limitations, the present experiments are an initial attempt to understand the mechanisms of regulation of MCP-1, a commonly identified chemokine in the perinatal period of preterm infants $(6-10)$.

Chorioamnionitis is associated with pulmonary expression of cytokines that have different sites of expression. IL-1 is expressed in inflammatory cells of the lung, whereas SAA3 and IP-10 are expressed mostly in the lung epithelium (32). We find that MCP-1 is expressed initially in the lung mesenchyme, predominantly fibroblasts, followed by expression in the inflammatory cells. These specific sites of expression may have implications for lung injury and repair.

Hyperoxia-induced pulmonary leukocyte accumulation in newborn mice is partly prevented with an anti-MCP-1 antibody (37), thus macrophage chemokine blockade may attenuate the inflammation that can impair lung development and result in BPD (38). Concentrations of MCP-1 in amniotic fluid are increased in women in preterm labor with or without chorioamnionitis, suggesting that MCP-1 may play a role in preterm labor regardless of the presence of chorioamnionitis (5,7). Plasma MCP-1 levels are increased for the first $21 \mathrm{~d}$ after birth in infants who developed BPD (9). Blood MCP-1 levels are increased in adults with atherosclerosis, acute myocardial infarction, and unstable angina (39). Thus, MCP-1 may be a nonspecific inflammatory marker and is a potential diagnostic biomarker for BPD. The expression profile of MCP-1 and MCP-2 in fetal sheep in response to LPS or IL-1 suggests that these cytokines may contribute to multiple inflammations associated pathologies in the preterm and deserve further study.

Acknowledgments. We thank Angela Keiser, Bill Hull, and Amy Whitescarver for their expert technical assistance.

\section{REFERENCES}

1. Goldenberg RL, Hauth JC, Andrews WW 2000 Intrauterine infection and preterm delivery. N Engl J Med 342:1500-1507

2. Yoon BH, Romero R, Jun JK, Park KH, Park JD, Ghezzi F, Kim BI 1997 Amniotic fluid cytokines (interleukin-6, tumor necrosis factor-alpha, interleukin-1 beta, and interleukin-8) and the risk for the development of bronchopulmonary dysplasia. Am J Obstet Gynecol 177:825-830

3. Holst RM, Hagberg H, Wennerholm UB, Skogstrand K, Thorsen P, Jacobsson B 2009 Prediction of spontaneous preterm delivery in women with preterm labor: analysis of multiple proteins in amniotic and cervical fluids. Obstet Gynecol 114:268-277

4. Keeler SM, Kiefer DG, Rust OA, Vintzileos A, Atlas RO, Bornstein E, Hanna N 2009 Comprehensive amniotic fluid cytokine profile evaluation in women with a short cervix: which cytokine(s) correlates best with outcome? Am J Obstet Gynecol 201:276.e1-276.e6

5. Jacobsson B, Holst RM, Wennerholm UB, Andersson B, Lilja H, Hagberg H 2003 Monocyte chemotactic protein-1 in cervical and amniotic fluid: relationship to microbial invasion of the amniotic cavity, intra-amniotic inflammation, and preterm delivery. Am J Obstet Gynecol 189:1161-1167

6. Chaiworapongsa T, Romero R, Tolosa JE, Yoshimatsu J, Espinoza J, Kim YM, Kim JC, Bujold E, Kalache K, Edwin S 2002 Elevated monocyte chemotactic protein-1 in amniotic fluid is a risk factor for pregnancy loss. J Matern Fetal Neonatal Med 12:159-164

7. Esplin MS, Romero R, Chaiworapongsa T, Kim YM, Edwin S, Gomez R, Mazor M, Adashi EY 2005 Monocyte chemotactic protein-1 is increased in the amniotic fluid of women who deliver preterm in the presence or absence of intra-amniotic infection. J Matern Fetal Neonatal Med 17:365-373

8. Esplin MS, Peltier MR, Hamblin S, Smith S, Fausett MB, Dildy GA, Branch DW, Silver RM, Adashi EY 2005 Monocyte chemotactic protein-1 expression is increased in human gestational tissues during term and preterm labor. Placenta 26:661-671

9. Ambalavanan N, Carlo WA, D'Angio CT, McDonald SA, Das A, Schendel D, Thorsen P, Higgins RD 2009 Cytokines associated with bronchopulmonary dysplasia or death in extremely low birth weight infants. Pediatrics 123:1132-1141

10. Natarajan G, Shankaran S, McDonald SA, Das A, Stoll BJ, Higgins RD, Thorsen P, Skogstrand K, Hougaard DM, Carlo WA 2010 Circulating beta chemokine and MMP 9 as markers of oxidative injury in extremely low birth weight infants. Pediatr Res 67:77-82

11. Laughon M, Allred EN, Bose C, O'Shea TM, Van Marter LJ, Ehrenkranz RA, Leviton A 2009 Patterns of respiratory disease during the first 2 postnatal weeks in extremely premature infants. Pediatrics 123:1124-1131

12. Andrews WW, Goldenberg RL, Faye-Petersen O, Cliver S, Goepfert AR, Hauth JC 2006 The Alabama Preterm Birth study: polymorphonuclear and mononuclear cell placental infiltrations, other markers of inflammation, and outcomes in 23- to 32-week preterm newborn infants. Am J Obstet Gynecol 195:803-808

13. Andrews WW, Cliver SP, Biasini F, Peralta-Carcelen AM, Rector R, AlrikssonSchmidt AI, Faye-Petersen O, Carlo W, Goldenberg R, Hauth JC 2008 Early preterm birth: association between in utero exposure to acute inflammation and severe neurodevelopmental disability at 6 years of age. Am J Obstet Gynecol 198:466.e1466.e 11

14. Gong X, Gong W, Kuhns DB, Ben-Baruch A, Howard OM, Wang JM 1997 Monocyte chemotactic protein-2 (MCP-2) uses CCR1 and CCR2B as its functional receptors. J Biol Chem 272:11682-11685

15. Lu B, Rutledge BJ, Gu L, Fiorillo J, Lukacs NW, Kunkel SL, North R, Gerard C, Rollins BJ 1998 Abnormalities in monocyte recruitment and cytokine expression in monocyte chemoattractant protein 1-deficient mice. J Exp Med 187:601-608

16. Harrington JR 2000 The role of MCP-1 in atherosclerosis. Stem Cells 18:65-66

17. Mahad DJ, Ransohoff RM 2003 The role of MCP-1 (CCL2) and CCR2 in multiple sclerosis and experimental autoimmune encephalomyelitis (EAE). Semin Immunol $15: 23-32$

18. Kallapur SG, Moss JT, Newnham JP, Ikegami M, Jobe AH 2005 Recruited inflammatory cells mediate endotoxin-induced lung maturation in preterm fetal lambs. Am J Respir Crit Care Med 172:1315-1321

19. Kallapur SG, Nitsos I, Moss TJ, Polglase GR, Pillow JJ, Cheah FC, Kramer BW, Newnham JP, Ikegami M, Jobe AH 2009 IL-1 mediates pulmonary and systemic inflammatory responses to chorioamnionitis induced by lipopolysaccharide. Am J Respir Crit Care Med 179:955-961

20. Willet K, Kramer BW, Kallapur SG, Ikegami M, Newnham J, Moss T, Sly P, Jobe A 2002 Intra-amniotic injection of IL-1 induces inflammation and maturation in fetal sheep lung. Am J Physiol Lung Cell Mol Physiol 282:L411-L420 
21. Sosenko IR, Kallapur SG, Nitsos I, Moss TJ, Newnham JP, Ikegami M, Jobe AH 2006 IL-1a causes lung inflammation and maturation by direct effects on preterm fetal lamb lungs. Pediatr Res 60:294-298

22. Struyf S, Van Collie E, Paemen L, Put W, Lenaerts JP, Proost P, Opdenakker G, Van Damme J 1998 Synergistic induction of MCP-1 and -2 by IL-1beta and interferons in fibroblasts and epithelial cells. J Leukoc Biol 63:364-372

23. Thurlbeck WM 1992 Prematurity and the developing lung. Clin Perinatol 19:497519

24. Kallapur SG, Willet KE, Jobe AH, Ikegami M, Bachurski C 2001 Intra-amniotic endotoxin: chorioamnionitis precedes lung maturation in preterm lambs. Am J Physiol Lung Cell Mol Physiol 280:L527-L536

25. Whitsett JA, Hull WM, Ohning B, Ross G, Weaver TE 1986 Immunologic identification of a pulmonary surfactant-associated protein of molecular weight $=6000$ daltons. Pediatr Res 20:744-749

26. Kallapur SG, Bachurski CJ, Le Cras TD, Joshi SN, Ikegami M, Jobe AH 2004 Vascular changes after intra-amniotic endotoxin in preterm lamb lungs. Am J Physiol Lung Cell Mol Physiol 287:L1178-L1185

27. Kallapur SG, Jobe AH, Ikegami M, Bachurski CJ 2003 Increased IP-10 and MIG expression after intra-amniotic endotoxin in preterm lamb lung. Am J Respir Crit Care Med 167:779-786

28. Takahashi M, Galligan C, Tessarollo L, Yoshimura T 2009 Monocyte chemoattractant protein-1 (MCP-1), not MCP-3, is the primary chemokine required for monocyte recruitment in mouse peritonitis induced with thioglycollate or zymosan A. J Immunol 183:3463-3471

29. Maus U, von Grote K, Kuziel WA, Mack M, Miller EJ, Cihak J, Stangassinger M, Maus R, Schlondorff D, Seeger W, Lohmeyer J 2002 The role of CC chemokine receptor 2 in alveolar monocyte and neutrophil immigration in intact mice. Am J Respir Crit Care Med 166:268-273

30. Beck-Schimmer B, Schwendener R, Pasch T, Reyes L, Booy C, Schimmer RC 2005 Alveolar macrophages regulate neutrophil recruitment in endotoxin-induced lung injury. Respir Res 6:61

31. Li X, Qin J 2005 Modulation of Toll-interleukin 1 receptor mediated signaling. J Mol Med 83:258-266

32. Wilson TC, Bachurski CJ, Ikegami M, Jobe AH, Kallapur SG 2005 Pulmonary and systemic induction of SAA3 after ventilation and endotoxin in preterm lambs. Pediatr Res 58:1204-1209

33. Gomez R, Romero R, Ghezzi F, Yoon BH, Mazor M, Berry SM 1998 The fetal inflammatory response syndrome. Am J Obstet Gynecol 179:194-202

34. Matsuda N, Hattori Y 2006 Systemic inflammatory response syndrome (SIRS): molecular pathophysiology and gene therapy. J Pharmacol Sci 101:189-198

35. Romero R, Gomez R, Ghezzi F, Yoon BH, Mazor M, Edwin SS, Berry SM 1998 A fetal systemic inflammatory response is followed by the spontaneous onset of preterm parturition. Am J Obstet Gynecol 179:186-193

36. Onderdonk AB, Delaney ML, DuBois AM, Allred EN, Leviton A 2008 Detection of bacteria in placental tissues obtained from extremely low gestational age neonates. Am J Obstet Gynecol 198:110.e1-110.e7

37. Vozzelli MA, Mason SN, Whorton MH, Auten RL Jr 2004 Antimacrophage chemokine treatment prevents neutrophil and macrophage influx in hyperoxiaexposed newborn rat lung. Am J Physiol Lung Cell Mol Physiol 286:L488-L493

38. Kallapur SG, Jobe AH 2006 Contribution of inflammation to lung injury and development. Arch Dis Child Fetal Neonatal Ed 91:F132-F135

39. Ikeda U, Matsui K, Murakami Y, Shimada K 2002 Monocyte chemoattractant protein-1 and coronary artery disease. Clin Cardiol 25:143-147 